\title{
RECYCLING OF Eucalipto cloeziana UNDER BIOCHAR DIFFERENT PYROLISIS TEMPERATURES
}

\author{
Evair Antônio Siebeneichler ${ }^{1}$, Liovando Marciano da $\operatorname{Costa}^{2}$, Natália Aragão de Figueredo ${ }^{3}$, \\ Jairo Tronto ${ }^{4}$
${ }^{2}$ Universidade Federal de Viçosa, Programa de Pós-Graduação em Solos e Nutrição de Plantas, Viçosa, Minas Gerais, Brasil - e-mail liovandomc@yahoo.com.br
${ }^{3}$ Instituto Federal Catarinense, Ibirama, Santa Catarina, Brasil- nataliaragao@ gmail.com e-mail
${ }^{4}$ Universidade Federal de Viçosa, Programa de Pós-Graduação em Química, Rio Paranaíba, Minas Gerais, Brasil - e-mail jairotronto@gmail.com \\ ${ }^{1}$ Engenheiro agrônomo autônomo, Chapecó, SC, e-mail: evair.eas@ gmail.com.
}

Received for publication: 17/10/2017 - Accepted for publication: 02/10/2018

\begin{abstract}
In the thermal decomposition of the biomass, products which include carbon compounds are generated. Biochar, a by-product of decomposition, has been efficient in retaining carbon, as well for agricultural and environmental management. Thus, the objective of this research is to evaluate the thermal stability and the recalcitrance of eucalyptus-derived bioburden due to different heating rates and pyrolysis temperatures. To do so, biochar were produced from Eucalyptus cloeziana at nine pyrolysis temperatures and three heating rates, and thermogravimetric analysis, determination of $\mathrm{C}$ and functional groups by FTIR were performed. Increasing the aromaticity of the biochromes produced, at higher temperatures, results in an increase in their recalcitrance, as demonstrated by the increase in thermal resistance and the oxidation by acid dichromate.
\end{abstract}

Keywords: carbon; stability; thermodecomposition.

\section{Resumo}

Recalcitrância do biocarvão de madeira de Eucalipto cloezina sob diferentes temperaturas de pirólise. Na decomposição térmica da biomassa são gerados produtos que compreendem diversos compostos de carbono. O biocarvão, subproduto desta decomposição, tem sido eficiente na retenção de carbono, contribuindo também para manejo agrícola e ambiental. Assim, este trabalho tem como objetivo avaliar a estabilidade térmica e a recalcitrância de biocarvões derivados de madeira de Eucalyptus cloeziana em função de diferentes taxas de aquecimento e temperaturas de pirólise. Para tanto, foram produzidos em nove temperaturas de pirólise e três taxas de aquecimento e realizadas análises termogravimétricas, determinação de $\mathrm{C}$ e grupos funcionais por FTIR. O aumento da aromaticidade dos biocarvões produzidos em maiores temperaturas resulta no aumento da recalcitrância destes, demonstrada pelo aumento da resistência térmica e à oxidação por dicromato em meio ácido.

Palavras-chave: carbono, estabilidade, termodecomposição.

\section{INTRODUCTION}

Pyrolysis technologies are promising for the conversion of biomass into renewable fuels and other derivatives, such as biochar, which provides benefits to agriculture, the economy and the environment. Pyrolysis of biomass can contribute to the mitigation of global warming by stabilizing part of biomass carbon in the form of coal and the production of bio-oil as an alternative to the use of fossil fuels as feedstock for energy production (HERATH et al., 2013).

Biochar has physical-chemical characteristics and can be used for environmental and agricultural practices. The use of biochar in the soil can increase yields of the crops by the following factors: reduction of leaching, $\mathrm{pH}$ improvement, increase of microbial activity and also by water retention (GLASER et al., 2002; SINGH et al., 2010) and removal of contaminants from water and soil (UCHIMIYA et al., 2015).

Regarding the environmental benefits, biochar has been a new scientific strategy for carbon storage due to its physical resistance, in which it remains in the soil for more than 100 years (LEHMANN et al.,; MANYÁ et al., 2012). Several investigations in several parts of the world have found coal in sedimentary deposits (MASIELLO \& DRUFFEL, 1998) and in soils (LIANG et al., 2006) with estimated ages varying from hundreds to thousands of years. 
Some researchers have suggested the proposal to store coal deep in the oceans or buried deep in the lithosphere (STALLARD, 1998; KINTISCH, 2007). These are certainly very efficient ways of storing carbon for long periods of time away from its fast cycle. Thus, the addition of biochar to soils, while retaining $\mathrm{C}$ in a stable form, also benefits the soil-plant system. This new allocation of coal is a recent issue and has attracted the interest of many scientists worldwide (LEHMANN et al., 2009; UCHIMIYA et al., 2015; ZHANG et al., 2013; GLAB et al., 2016).

The persistence of coal in the environment for so long is due to its polycyclic aromatic structure (GLASER et al., 2002). Carbonized materials have some functional groups that can be ionized (carboxylic and phenolic), through which they are able to associate with the soil components and form part of the soil structure. A part of the $\mathrm{C}$ can be degraded biotically and abiotically (chemical oxidation, photo-oxidation and solubilization), but at very low velocity and another part remains unchanged, increasing its permanence in the environment (ZIMMERMANN, 2010).

However, the properties of the biochar depend on the raw material used and on the thermochemical conversion conditions, including temperature, oxygen level and reaction time (ZHANG et al., 2013). These physico-chemical properties influence, among other attributes, the surface area, structure, porosity and elemental composition that are determinant in the ability to sequester $\mathrm{C}$ and in agricultural benefits, such as: water retention, nutrient fixation and immobilization of pollutants (UCHIMIYA et al., 2015).

Thus, the efficiency of the use of biochar for agricultural and environmental purposes depends on the treatment used and the pyrolysis conditions. Thus, further studies on the chemical and physical characteristics of biochar are needed to assess its effective form of $\mathrm{C}$ retention and agricultural and environmental management. Thus, the objective of this work was to evaluate the thermal stability and the recalcitrance of biocarbons from Eucalyptus wood, due to different heating rates and pyrolysis temperatures to contribute to research on the use of biochar for environmental purposes.

\section{MATERIAL AND METHODS}

Biochar was derived from eucalyptus wood (Eucalyptus cloeziana; 7 years of age) in $10 \times 1 \times 1 \mathrm{~cm}$ of dimensions that were oven dried at $105{ }^{\circ} \mathrm{C}$ for $24 \mathrm{~h}$. The pyrolysis was carried out in a muffle furnace with nine pyrolysis temperatures (PT), being 300, 350, 400, 450, 500, 550, 600, 650 and $700{ }^{\circ} \mathrm{C}$ and three heating rates (HR), 5, 22,5, and $40{ }^{\circ} \mathrm{C} \mathrm{min}^{-1}$ according to studies by Ranzi et al., 2008. The residence time at the final pyrolysis temperature was $15 \mathrm{~min}$, and afterwards it was stored in a desiccator. This procedure is necessary because the coal undergoes oxidation reactions in contact with the atmosphere, changing the amount of active surface groups (loads) (BOEHM, 2008).

Determinations of the $\mathrm{C}, \mathrm{H}$ and $\mathrm{N}$ contents were made on an elemental analyzer (PerkinElmer 2400 Series II CHNS / O). The recalcitrance of the coals produced was compared by TG-DTA and dichromate oxidation analyses. The TG-DTA analysis was done in a Netzsch STA 409EP apparatus, with air atmosphere, heating rate

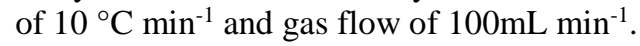

The ratio between the most recalcitrant and less recalcitrant compounds has been used as an index to characterize the thermal stability of the soil organic matter (PLANTE et al., 2009). However, in coals produced at 600 and $700{ }^{\circ} \mathrm{C}$ there was little mass loss associated with less recalcitrant compounds, and in coal produced at 400 and $500{ }^{\circ} \mathrm{C}$, it is not possible to establish a defined boundary distinguishing between these classes of compounds, making that this index has little value for the characterization of the thermal coals' stability. Thus, the thermodecomposition of $50 \%$ of the initial mass, the maximum mass loss rate during the last thermal event, and the remaining initial mass fraction were used as measurements of the thermal coals' stability at a temperature of $400{ }^{\circ} \mathrm{C}$. This temperature was used according to the SIEBENEICHLER et al. (2017) study which found out that increasing in temperature and heating rate increases the occurrence of ruptures in coal's structure, with consequent physical resistance reduction.

The determination of $\mathrm{C}$ by oxidation with potassium dichromate was performed by the methods of Walkley \& Black (1934) (unheated) and Yeomans \& Bremner (1988) (with heating), following the methodology described for soil analysis by Mendonça \& Matos 2005). The data were statistically treated by analysis of variance by the $\mathrm{F}$ test and the means of the treatments compared by the $\mathrm{T}$ test at $5 \%$ of significance (DMS 5\%). 


\section{RESULTS}

The eucalyptus wood used in this study has $46.9,0.62,6.46$ and $45.8 \mathrm{dag} \mathrm{kg}^{-1}$ of $\mathrm{C}, \mathrm{N}, \mathrm{H}$ and $\mathrm{O}$ respectively. Similar contents to these were found in other studies with eucalyptus (Garcia-Perez et al., 2008; Cuña Suárez et al., 2010). These four elements account for $99.8 \%$ of the wood mass, being only $0.20 \%$ due to other elements. Most of the loss of the four elements occurred with heating up to $400{ }^{\circ} \mathrm{C}$. From this temperature, most of the mass reduction of the biochars was due to the loss of $\mathrm{O}$ and $\mathrm{H}$, whereas the volatilization of $\mathrm{C}$ and $\mathrm{N}$ became very slow. As a consequence, the $\mathrm{C}$ content accounted for $89 \%$ of the carbon mass produced in the PT at $700{ }^{\circ} \mathrm{C}$. At this same temperature, on average for the three $\mathrm{HR}$, the elements $\mathrm{N}, \mathrm{H}$ and $\mathrm{O}$ corresponded to approximately $0.42 ; 2.2$ and $7.7 \%$ of the biochars' mass, respectively. This behavior reflects in the $\mathrm{H} / \mathrm{C}, \mathrm{O} / \mathrm{C}$, $\mathrm{C} / \mathrm{N}$ and $\mathrm{H} / \mathrm{O}$ relations, in which the $\mathrm{H} / \mathrm{C}$ and $\mathrm{O} / \mathrm{C}$ relations were higher at temperatures below $500{ }^{\circ} \mathrm{C}$ while the $\mathrm{C} / \mathrm{N}$ and $\mathrm{H} / \mathrm{O}$ were higher when the pyrolysis temperature increases (Figure 1).
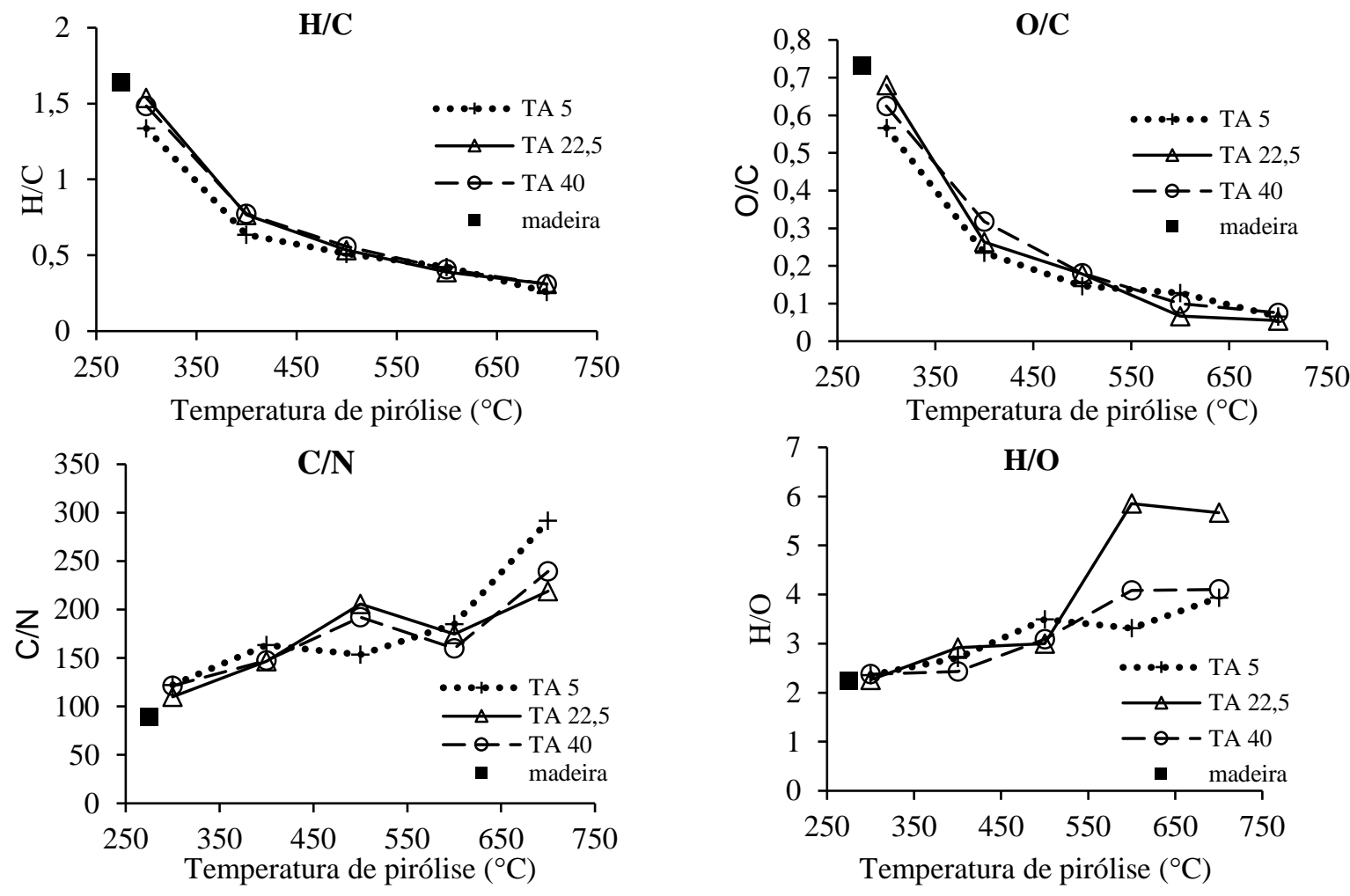

Figure 1. Relationship of $\mathrm{C}, \mathrm{N}, \mathrm{H}$ and $\mathrm{O}$ in the charcoals produced at different temperatures and heating rate.

Figura 1. Relação de $\mathrm{C}, \mathrm{N}, \mathrm{H}$ e $\mathrm{O}$ nos carvões produzidos a diferentes temperaturas e taxa de aquecimento.

In the thermogravimetric (TG) and differential thermal analysis (DTA) presented by the thermograms of Figure 2, the similar behavior of the biochar produced at $300{ }^{\circ} \mathrm{C}$ with the one of the wood can be associated. The decomposition of hemicellulose and cellulose present in the wood occur between $278-280^{\circ} \mathrm{C}$ and 342 and $347^{\circ} \mathrm{C}$, respectively (PEREIRA et al., 2013).

The temperature at which the maximum mass loss rate occurred increased by an average of $5{ }^{\circ} \mathrm{C}$ for each $100{ }^{\circ} \mathrm{C}$ increase in the PT of the coals produced between 300 and $600{ }^{\circ} \mathrm{C}$, and an increase of $30^{\circ} \mathrm{C}$ occurred between the coals produced in $600{ }^{\circ} \mathrm{C}$ for those of $700{ }^{\circ} \mathrm{C}$. This difference in temperature is a proposition that there was a differentiated stability in these coals compared to the others. 

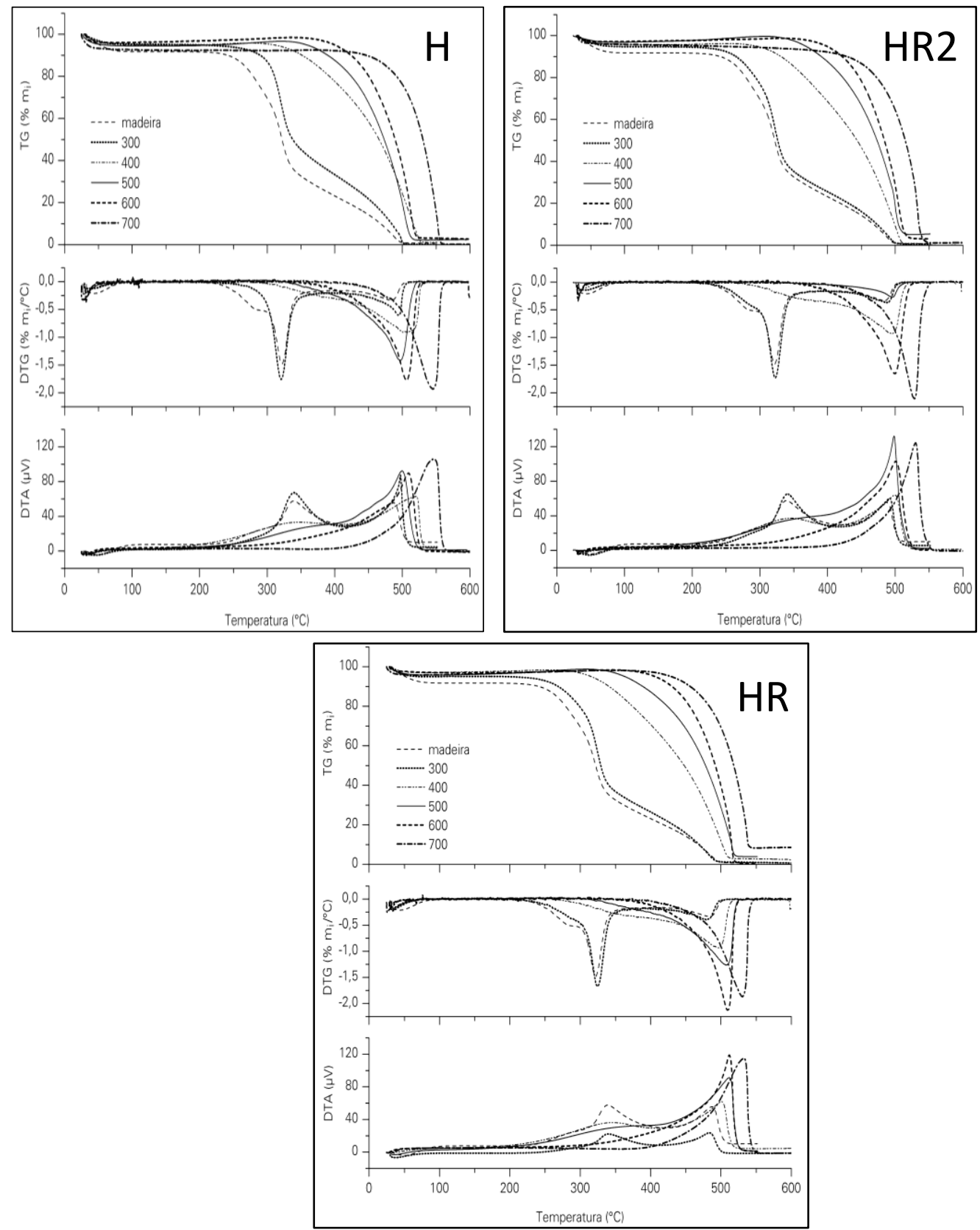

Figure 2. Thermogravimetric analysis in the air atmosphere of the carbons produced with HR5; 22.5 and $40 . \mathrm{m}_{\mathrm{i}}=$ initial mass

Figura 2. Análises termogravimétricas em atmosfera de ar dos carvões produzidos com TA5; 22,5 e 40. mi = massa inicial

The main groups identified were: $\mathrm{O}-\mathrm{H}, \mathrm{C}-\mathrm{H}, \mathrm{C}=\mathrm{O}, \mathrm{C}=\mathrm{C}, \mathrm{C}-\mathrm{H}, \mathrm{C}-\mathrm{O}$. The broadband in the region of 3600 to $3000 \mathrm{~cm}^{-1}$ is assigned to $\mathrm{H}$-bonding $\mathrm{O}-\mathrm{H}$ and $\mathrm{N}-\mathrm{H}$ bonds, which may belong to the phenol, alcohol and carboxylic groups. The $\mathrm{O}-\mathrm{H}$ groups participating in hydrogen bonds absorb in the region of 3200 to $3550 \mathrm{~cm}^{-1}$, while the groups that do not participate in this type of bond absorb about $3600 \mathrm{~cm}^{-1}$, which form narrower bands (SILVERSTEIN et al., 2007) (Figure 3). 


\section{HR5}

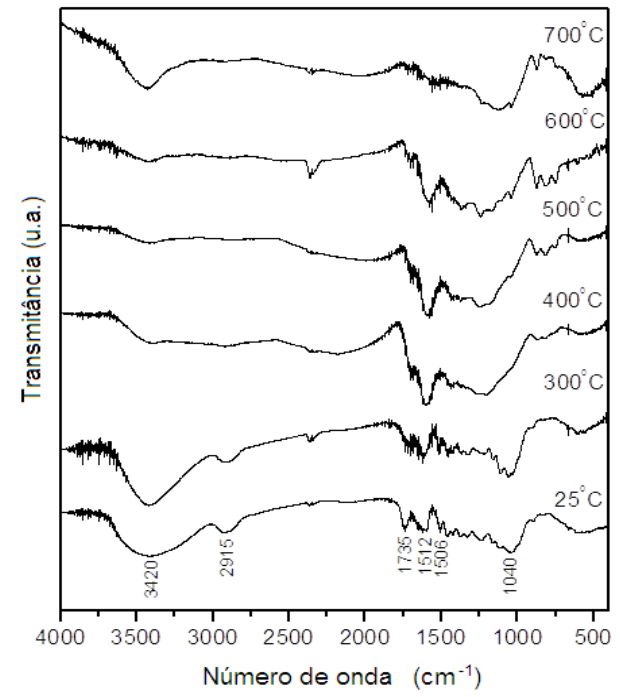

HR22,5

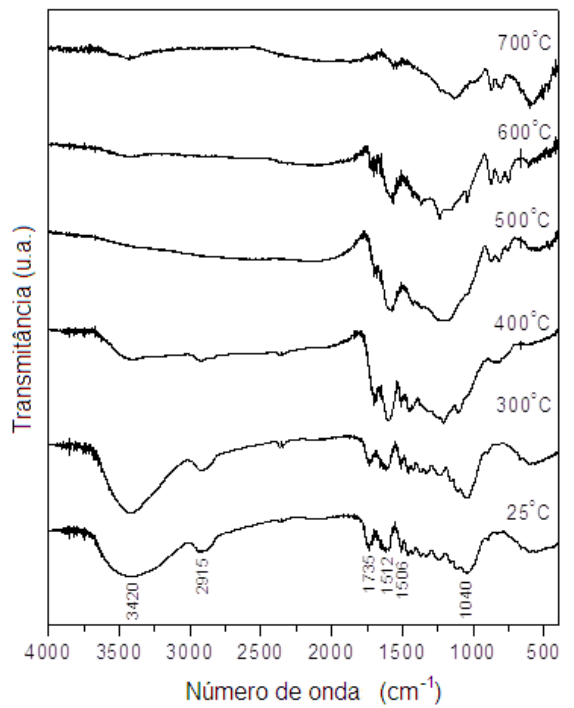

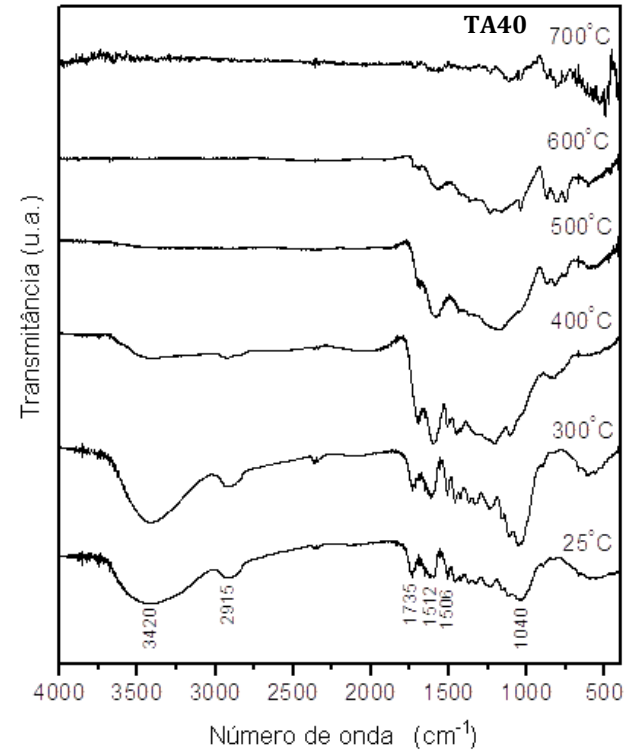

Figure 3. Infrared spectra of the wood and the biochar produced at different temperatures and heating rate.

Figura 3. Espectros de infravermelho da madeira e dos biocarvões produzidos a diferentes temperaturas e taxa de aquecimento.

The temperature needed to cause the loss of 50\% of the initial mass (T50) and the portion of the initial mass remaining at $400{ }^{\circ} \mathrm{C}(\mathrm{R} 400)$ were linearly correlated with each other $(\widehat{\mathrm{T} 5} 0=262.7+2.470 \mathrm{R} 400 ; \mathrm{r}=0.985)$ and the molar relation $\mathrm{H} / \mathrm{C}$ (aromaticity index) of wood and biochars (Figure 4). The T50 and R400 also have excellent linear correlation with the $\mathrm{O} / \mathrm{C}$ molar relation, which is another index that indicates the thermal decomposition of the biomass. 

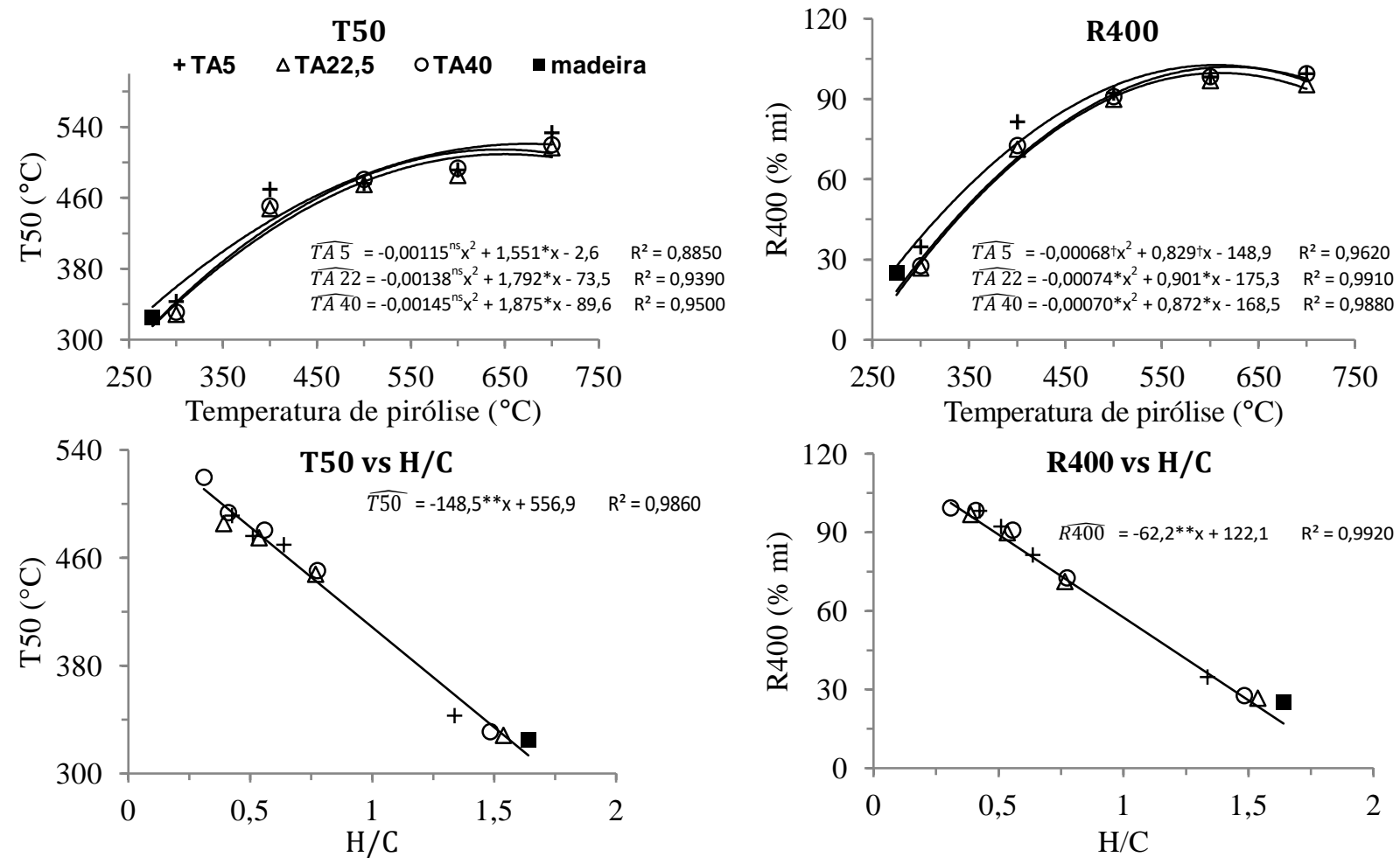

Figure 4. Temperature for the loss of $50 \%$ (T50) of initial mass $\left(\mathrm{m}_{\mathrm{i}}\right)$, portion of initial mass remaining at $400^{\circ} \mathrm{C}$ (R400). Symbols ${ }^{* *},{ }^{*}$ and ${ }^{\dagger}$ on the regression coefficients represent significance of 1,5 or $10 \%$, respectively.

Figura 4. Temperatura para a perda de $50 \%$ (T50) da massa inicial (mi), porção da massa inicial remanescente na temperatura de $400^{\circ} \mathrm{C}(\mathrm{R} 400)$. Símbolos ${ }^{* *},{ }^{*} \mathrm{e} \dagger$ sobre os coeficientes das regressões representam significância de 1,5 ou $10 \%$, respectivamente.

Resistance of $\mathrm{C}$ to oxidation by the Walkley and Black (WB) method increased with increasing PT. The heating rates differ only in PT of $400{ }^{\circ} \mathrm{C}$ (Figure 5). The $\mathrm{C}$ content was estimated considering its oxidation state as being +0.194 . The amount of $\mathrm{C}$ determined in the wood and in the biochars produced at $300{ }^{\circ} \mathrm{C}$ by the WB method was equivalent to $101 \%$ of the amount determined in the elemental analyzer. This result confirms the assumptions made in estimating the oxidation state of $\mathrm{C}$.

As consequence of the increased chemical stability of the biochars produced at temperatures above 300 ${ }^{\circ} \mathrm{C}$, the total $\mathrm{C}$ portion determined by the WB method dropped to approximately $16.5 \%$ in the $400{ }^{\circ} \mathrm{C}$ biochar produced at HR22.5 and HR40 and 9\% in HR5, and gradually reduced to about $4.5 \%$ in the $700{ }^{\circ} \mathrm{C}$ biochars.
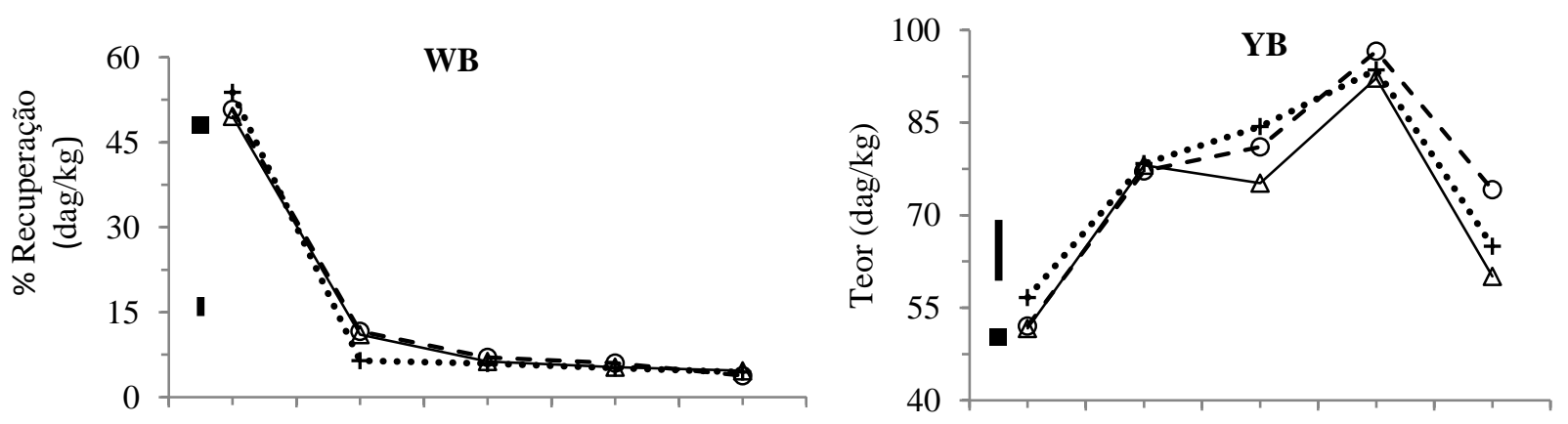

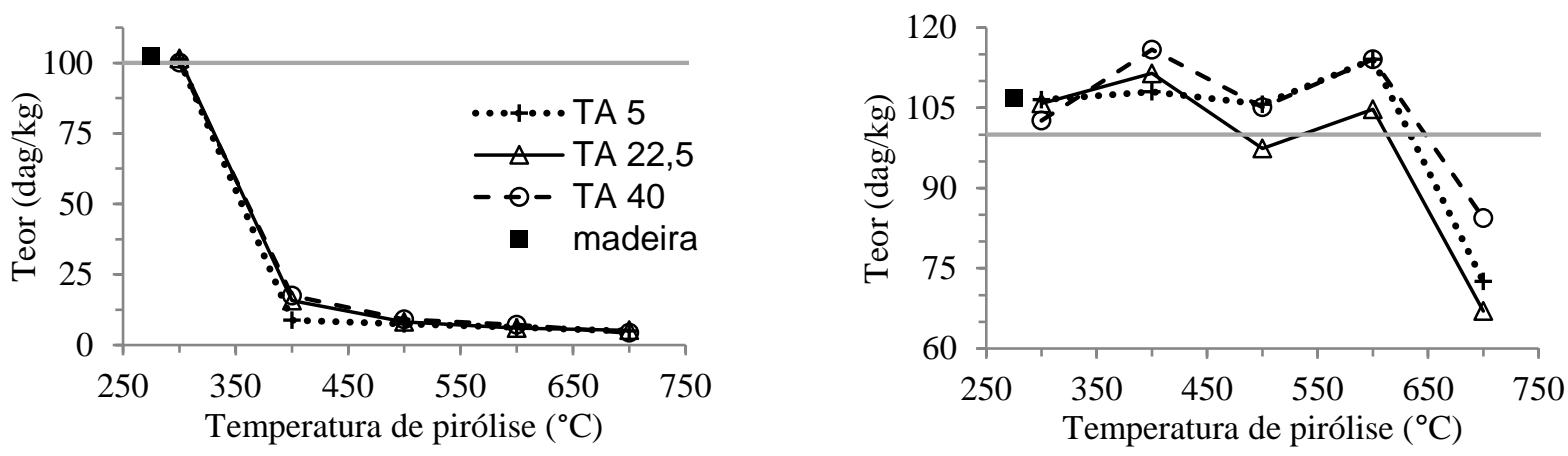

Figure 5. C content in wood and biochar determined by the Walkley and Black (WB) and Yoemans and Bremner (YB) methods, with their respective recovery rates in relation to total (WB / T, YB / T).

Figura 5. Teor de $\mathrm{C}$ na madeira e nos biocarvões determinado pelos métodos Walkley e Black (WB) e Yoemans e Bremner (YB), com suas respectivas taxas de recuperação em relação ao teor total (WB/T, YB/T).

Discounting from the amount of $\mathrm{C}$ of the biomass recovered in the biochar the amount of C-labile by the WB method, it is estimated that the pyrolysis of the wood at $400{ }^{\circ} \mathrm{C}$ provides the stabilization of greater amount of $\mathrm{C}$, about $51 \%$ of the $\mathrm{C}$ of the biomass (Figure 6).

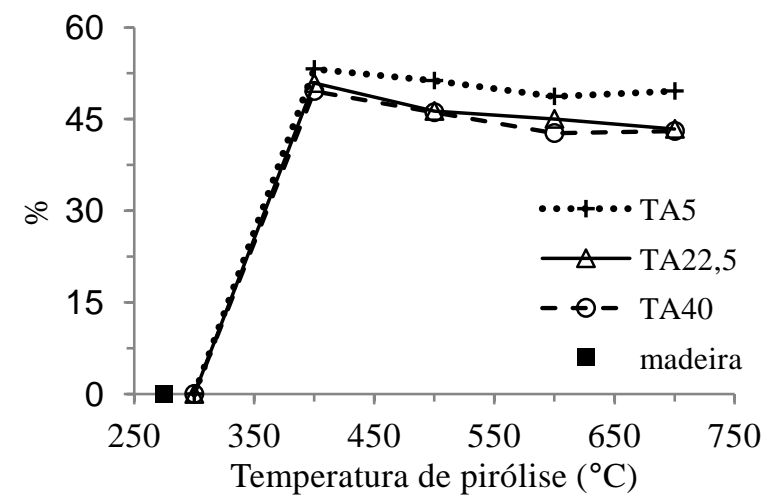

Figure 6. Quantity of $\mathrm{C}$ recovered in biochar and recalcitrant to Walkley-Black as a function of pyrolysis temperature and heating rate.

Figura 6. Quantidade de C recuperada nos biocarvões e recalcitrante ao Walkley-Black em função das temperaturas de pirólise e taxas de aquecimento.

\section{DISCUSSION}

Biochars produced at $\mathrm{HR} 5{ }^{\circ} \mathrm{C} / \mathrm{min}$ are more resistant to thermal decomposition. With the increase of TA it is possible to identify a decrease in mass as a function of PT. However, with the increase of PT, a mass loss occurs over a wide temperature range, which allows to associate it to the compounds that were produced during the pyrolysis. This wide temperature range expressed by the DTA with peaks of energy at approximately $500{ }^{\circ} \mathrm{C}$ were very similar for all heating rates.

At high heating rates, the decomposition of hemicellulose, cellulose and lignin occurs. In this condition, the heat and mass transfer on the surface of the biomass particles is accelerated, and the biochar produced presents higher cracks, higher specific surface area and higher porosity, but lower mechanical resistance (BYRNE \& NAGLE, 1997).

The $\mathrm{O} / \mathrm{C}$ and $\mathrm{H} / \mathrm{C}$ relations decreased with the increasing pyrolysis temperature, which characterizes higher $\mathrm{C}$ stability in these biochars. In all treatments a low $\mathrm{H} / \mathrm{C}$ and $\mathrm{O} / \mathrm{C}$ relation was obtained, which may reflect a higher proportion of aromatic rings in the structure of these carbons. Biochar with temperatures below $500{ }^{\circ} \mathrm{C}$ showed lower $\mathrm{C} / \mathrm{N}$ and $\mathrm{H} / \mathrm{O}$ relations and higher $\mathrm{H} / \mathrm{C}$ and $\mathrm{O} / \mathrm{C}$, which indicates the presence of functional groups of dissolved organic carbon (OLIVEIRA et al., 2017).

The lower proportion of $\mathrm{O} / \mathrm{C}$ and $\mathrm{H} / \mathrm{C}$ in the biochar correlates directly with the aromatic structure and its biodegradation properties and also their polarity, which are highly desirable properties, for example for the removal of pollutants (CROMBIE et al., 2013). The H/C value reflects the aromatization of the organic matter, 
while the $\mathrm{O} / \mathrm{C}$ value reflects the functional group content, hydrophobicity and the stability of the biochar in the soils (TAN et al., 2017). Thus, the increase in aromaticity and C content improves the stability of the biochar.

In the biochars produced at $300{ }^{\circ} \mathrm{C}$ there is a reduction in absorption around $3200 \mathrm{~cm}^{-1}$ due to both the loss of water adsorbed on the wood structure and the thermodecomposition of carboxylic and alcoholic groups of cellulose (FIGUEIREDO et al., 1999). These bands, along with the band around $2915 \mathrm{~cm}^{-1}$, attributed to C-H groups of aliphatic chains, virtually disappear in the biochars produced at temperatures above $400^{\circ} \mathrm{C}$ at all $\mathrm{HR}$. Only the biochars produced in the HR5 show some absorption in the band around $3420 \mathrm{~cm}^{-1}$, attributed to the water that these biochars became able to adsorb with increasing porosity.

The region 1750 to $1000 \mathrm{~cm}^{-1}(\mathrm{C}=\mathrm{O})$ shows peaks of a large diversity of functional groups, and exact assignment in this region of the spectrum is difficult. All of these groups resisted the $300{ }^{\circ} \mathrm{C}$ treatment to a greater or lesser extent. However, most of these bands disappeared with heating above $400{ }^{\circ} \mathrm{C}$ at $\mathrm{HR} 5$ and above $500^{\circ} \mathrm{C}$ at HR22.5 and HR40. At heating from $400^{\circ} \mathrm{C}$, the peaks previously centered at 1735 and $1620 \mathrm{~cm}^{-1}$ were around 1700 and $1600 \mathrm{~cm}^{-1}$ as a result of structural and/or stereochemical changes.

The $\mathrm{C}=\mathrm{C}$ group of aromatic compounds $\left(1600-1475 \mathrm{~cm}^{-1}\right)$ is one of the few remaining to be heated to 700 ${ }^{\circ} \mathrm{C}$, along with the band around $1240 \mathrm{~cm}^{-1}$ which can be attributed to draw $\mathrm{C}-\mathrm{O}$ and angular deformation $\mathrm{O}-\mathrm{H}$ of carboxylic groups. According to Pastor-Villegas et al. (2007), some bands between 900 and $1300 \mathrm{~cm}^{-1} \mathrm{can} \mathrm{be}$ assigned to the group $\mathrm{C}-\mathrm{O}-\mathrm{C}$ present on graphite sheets, or between two blades, where $\mathrm{O}$ may act as a bridge between the aromatic blades.

The H/C molar relation was chosen for the interpretations because its correlation with the rates of thermal stability and recalcitrance of $\mathrm{C}$ to the oxidation with dichromate, which was slightly higher than the correlation of these with the O/C molar relation. Despite the high correlation between T50 and R400, it is important to remember that they determine different characteristics of the sample. While the former corresponds to the temperature required to cause the thermodecomposition of half of the sample mass, the second is a measure of the amount of resistant compounds at a predetermined temperature. Thus, future work should be performed to confirm the correlation between the T50 and R400 indexes.

The $\mathrm{C}$ content determined by the Yoemans and Bremner (YB) method was on average $8 \%$ higher than the content determined by the elemental analyzer in the wood and in the biochars produced at temperatures up to $600{ }^{\circ} \mathrm{C}$. Thus, the $\mathrm{C}$ content recovered by the YB method is interpreted only qualitatively, associating the lower recovery of $\mathrm{C}$ in the biochars produced at $700{ }^{\circ} \mathrm{C}$ to their greater stability. The fact that the WB method does not identify any abrupt change in the labile $\mathrm{C}$ content, as observed in thermogravimetric analyzes and by the YB method, it suggests that the compounds produced during the pyrolysis undergo different degrees of stabilization, acquiring differentiated degrees of chemical and thermal resistance.

Several research groups have already studied the kinetics of biochar mineralization by means of incubation tests. However, few attempted to calibrate any method to predict the rate of mineralization or the amount of mineralizable $\mathrm{C}$ in a given period of time. As the decomposition of these compounds occurs at temperatures below $400^{\circ} \mathrm{C}$, it is possible that the $\mathrm{R} 400$ index may have good applicability in studies on the stability of the biochar. As the decomposition of the organic compounds depends on a range of factors, the search for methods of predicting the stability of these compounds in the environment constitutes an analytical challenge.

However, the characterization of the biochars by methods that allow to infer about the recalcitrance of their compounds of $\mathrm{C}$ can be of great assistance for the obtained results comparison between different groups of researches. With the proposal to include biochar production in the C credits market (LEHMANN et al., 2009) it will be necessary to have some method to characterize the biochars as to the effectiveness with which they will act as $\mathrm{C}$ drain (time and quantity).

\section{CONCLUSIONS}

- The pyrolysis temperature is an important factor for the thermal stability of the coals.

- Pyrolysis at temperatures below $400{ }^{\circ} \mathrm{C}$, despite the higher recovery of wood $\mathrm{C}$ in biochar, does not contribute to the stabilization of $\mathrm{C}$.

- Temperatures above $400{ }^{\circ} \mathrm{C}$ increase the thermal stability of the biochars and the recalcitrance of the $\mathrm{C}$ to the Walkley-Black method.

\section{ACKNOWLEDGMENTS}

A Coordination for the Improvement of Higher Level Personnel for granting the scholarship.

\section{REFERENCES}

BOEHM, H.P. Surface chemical characterization of carbons from adsorption studies. In: BOTTANI, EJ, TASCÓN, JMD eds. Adsorption by carbons. Elsevier, v.8, p.301-328, 2008. 
BYRNE, C.E.; NAGLE, D.C. Carbonized wood monoliths - characterization. Carbon, Elsevier, v.35, n.2, p.267273, 1997.

CROMBIE, K., MAŠEK, O., SOHI, S.P., BROWNSORT, P., Cross, A. The effect of pyrolysis conditions on biochar stability as determined by three methods. GCB Bioenergy, Geneva, v.5, n.2, p.122-131, 2013.

FIGUEIREDO, J.L.; PEREIRA, M.F.R.; FREITAS, M.M.A.; ÓRFÃO, J.J.M. Modification of the surface chemistry of activated carbons. Carbon, Elsevier, v.37, n.9, p.1379-1389, 1999.

GARCIA-PEREZ, M.; WANG, S.; SHEN, J.; RHODES, M.J.; LEE, W.-J.\& LI, C.-Z. Effects of temperature on the formation of lignin-derived oligomers during the fast pyrolysis of Mallee woody biomass. Energy Fuels, 22:2022-2032, 2008a.

GŁĄB. T; PALMOWSKA, J.; ZALESKI, T.; GONDEK, K. Effect of biochar application on soil hydrological properties and physical quality of sandy soil. Geoderma, v. 281, p.11-20, 2016.

GLASER, B.; LEHMANN, J.; ZECH, W. Ameliorating physical and chemical properties of highly weathered soils in the tropics with charcoal - a review. Biology and Fertility of Soils, Oxford, v.35, n.4, p.219-230, 2002.

HERATH, H.M.S.K.; CAMPS-ARBESTAIN, M.; HEDLEY, M. Effect of biochar on soil physical properties in two contrasting soils: an Alfisol and an Andisol. Geoderma, v.209, p. 188-197, 2013.

KINTISCH, E. Report backs more projects to sequester CO2 from coal. Science, Washington, v. 51, n.4, p. 315:1481, 2007.

LEHMANN, J.; JOSEPH, S. Biochar for environmental management: an introduction. In: LEHMANN, J.; JOSEPH, S., eds. Biochar for environmental management: science and technology. London: Earthscan, 2 ed. 2009. 256p.

LIANG, B.; LEHMANN, J.; SOLOMON, D.; KINYANGI, J.; GROSSMAN, J.; O’NEILL, B.; SKJEMSTAD, J.O.; THIES, J.; LUIZÃO, F.J.; PETERSEN, J.; NEVES, E.G. Black carbon increases cation exchange capacity in soils. Soil Science Society of America, Fitchburg, v.70, n.7, p.1719-1730, 2006.

MANYÀ, J.J. Pyrolysis for biochar purposes: a review to establish current knowledge gaps and research needs. Environmental Science \& Technology, Washington, v.46, n.15, p.7939-7954, 2012.

MASIELLO, C.A.; DRUFFEL, E.R.M. Black carbon in deep-sea sediments. Science, Washington, v. 280, n.1, p.1911-1913, 1998.

MENDONÇA, E.S.; MATOS, E.S. Matéria orgânica do solo: métodos de análise. Viçosa: Editora UFV, 2ed. 2005, 107p.

OLIVEIRA, F.R.; PATEL, A.K.; JAISI, D.P.; ADHIKARI, S.; LU, H. Environmental application of biochar: Current status and perspectives. Bioresource Technology, Melia Sitges, v.22, n.2, p.8-16, 2017.

PASTOR-VILLEGAS, J.; MENESES RODRÍGUEZ, J.M.; PASTOR-VALLE, J.F.; GARCÍA, M. Changes in commercial wood charcoals by thermal treatments. Journal of Analytical and Applied Pyrolysis, Nancy, v.80, n.2, p.507-514, 2007.

PEREIRA, B.L.C; CARNEIRO, A.C.; CARVALHO, A.M.M.L; TRUGILHO, P.F.;MELO, I.C.N.A.; OLIVIERA, A.C. Estudo da degradação térmica da madeira de Eucalyptus através de termogravimetria e calorimetria. Revista Árvore, v.37, n.3, 2013.

PLANTE, A.F.; FERNÁNDEZ, J.M.; LEIFELD, J. Application of thermal analysis techniques in soil science. Geoderma, Tumbledown, v.153, n.3, p.1-10, 2009.

SINGH, B.; SINGH, B.P.; COWIE, A.L. Characterisation and evaluation of biochars for their application as a soil amendment. Australian Journal of Soil Research, Clayton South, v.48, n.3, p.516-525, 2010.

SIEBENEICHLER, E. A.; COSTA, L. M. ; FIGUEREDO, N. A. ; TRONTO, J. ; ROCHA, P. A. Influência de temperatura e taxas de aquecimento na resistência mecânica, densidade e rendimento do carvão da madeira de Eucalyptus cloeziana. Ciência da madeira, v. 8, p. 82-94, 2017.

SILVERSTEIN, R.M.; WEBSTER, F.X.; KIEMLE, D.J. Identificação espectrométrica de compostos orgânicos. Rio de Janeiro: LTC, 7.ed. 2007, 490p. 
STALLARD, R.W. Terrestrial sedimentation and the carbon cycle: coupling weathering and erosion to carbon burial. Global Biogeochemical Cycles, Washington, v.12, n.2, p.231-257, 1998.

TAN, X.F., LIU, S.B., LIU, Y.G., GU, Y.L., ZENG, G.M., HU, X.J., WANG, X., LIU, S.H., JIANG, L.H., 2017. Biochar as potential sustainable precursors for activated carbon production: multiple applications in environmental protection and energy storage. BioSource Technology, Melia Sitges, v.227, n.1, p. 359-372.

UCHIMIYA M.; HIRADATE, S.; ANTAL, M.J. Dissolved phosphorus speciation of flash carbonization, slow pyrolysis, and fast pyrolysis biochars. ACS Sustainable Chemistry \& Engineering, Washington, v.3, n.7, p.1642-1649, 2015.

YOEMANS, J.C.; BREMNER, J.M. A rapid and precise method for routine determination of organic carbon in soil. Journal Communications in Soil Science and Plant Analysis, Georgia. v.19, n.3, p.1467-1476, 1988.

ZIMMERMAN, A.R. Abiotic and microbial oxidation of laboratory-produced black carbon (biochar). Environmental Science \& Technology, Washington, v.44, v.4, p.1295-1301, 2010.

ZHANG, W.; MA, S.; CHEN, H.; HUANG, L.; QIU, R. Pb(II) and Cr(VI) sorption by biochars pyrolyzed from the municipal wastewater sludge under different heating conditions. Bioresource Technology, Melia Sitges, v.147, n. 2, p.545-552, 2013. 